\title{
Apt transformative path to Sustainable Development post COVID 19 pandemic: How lifelong learning should be revivified for the recovery of countries
}

Dama Mosweunyane (PhD)

\begin{abstract}
The purpose of this paper is to advance the view that Lifelong Learning should be revivified for the fulfilment of the development recovery programmes of countries post COVID 19 pandemic. The informed position that the paper presents is that COVID 19 pandemic that has devastated the global economy and brought about social, political and environmental challenges, requires lifelong learning if sustainable development is to be realised. It is so because Lifelong Learning has capacity to serve as a vehicle for the education of the populace, which is important for the realisation of Sustainable Development. Lifelong Learning is the concept that allows the people to acquire knowledge, skills and attitudes from the time they are conceived to the time of their deaths (Womb to tomb). It is therefore pivotal to indicate that lifelong learning should be employed by countries in their recovery programmes from the effects of COVID 19 pandemic. It should motivate people to fully participate in the transformative processes that are geared towards the fulfilment of Sustainable Development. The function of Lifelong Learning in the reactivation of various sectors post COVID 19 cannot be undermined, hence the call by this paper for it to be revivified. To revivify Lifelong Learning will make it more relevant in the routing of the countries towards achieving Sustainable Development post the ravage that will be caused by the pandemic.
\end{abstract}

Keyword: Lifelong Learning, Sustainable Development, COVID 19, transformative and revivification.

DOI: $10.7176 / \mathrm{JAAS} / 76-05$

Publication date:October $31^{\text {st }} 2021$

\section{Introduction}

The emergence of the coronavirus disease 19 (COVID-19), which is a highly transmittable and pathogenic viral infection caused by severe acute respiratory syndrome coronavirus 2 (SARS-CoV-2) has led to a dramatic loss of human life worldwide (Sheen et al (2020). This human tragedy therefore requires countries to respond quickly and decisively, with full participation and cooperation of their people irrespective of their socio-economic status, age, educational qualifications and colour, if mortality rate is to be lowered. The need for the timely recovery cannot be overemphasised, owing to the negative economic, social and environmental impact the tragedy has caused and continue to cause. The economies are dealt a blow and the people get affected socially as they can no longer assemble and undertake social activities that had for years defined their existence. In the environmental sphere the nations expend more resources, such as use of more land to bury those whose lives are ended by the pandemic. The countries that bury corpses instead of cremations face a challenge of allocating more land for cemeteries, which could instead be utilised for excellent food production to combat food insecurity. It is important to note that agriculture will play a pivotal global role in the recovery of economies of countries post the pandemic.

To provide a relevant example of Botswana, which is a country with vast amount of land, it is necessary for the country to utilise its educational entities to promote Sustainable Development, with the full aim of saving the land and other natural resources for posterity. Botswana, according to The World Bank (2019) has a land mass of $581.730 \mathrm{~km} 2$ and a population of 2.304 million people. However, if the country does not legislate against the sale of land to foreigners to bury bodies of people who may have come into the country as expatriates and their dependants, this will aggravate serviced land shortage. It is therefore important for legislators to be educated through institutions such as parliament, so that they can appreciate formation of legislations against the sale of land to foreigners, which has led to civil strives in countries such as Palestine.

It is therefore important for countries to embark on the use of lifelong learning, which is pivotal in the education of the people in changing their mind-sets so that they utilise finite resources parsimoniously with the view to saving them for posterity. Lifelong learning has the cognitive dimension of knowledge and skills, the emotional dimension of feelings and motivation, and the social dimension of communication and co-operation - all of which are embedded in a societally situated context (Illeris, 2010). It is the aforementioned qualities of Lifelong learning that are important if Sustainable Development is to be realised at national, regional and global levels. As noted by Encarta (2008) a simple definition of lifelong learning is that it is "development after formal education: the continuing development of knowledge and skills that people experience after formal education and throughout their lives". The Director of UNESCO Institute for Lifelong Learning Arne Carlsen in 2015 pointed out some comprehensive relationship between Lifelong Learning and Sustainable Development when he stated that, Lifelong Learning is becoming increasingly important in today's world and is an integral part of the 2030 Agenda for Sustainable Development.

\section{Economic transformation amid profligacy}

It is indisputable that almost all the countries have suffered economic devastation due to resultant lack of activities that generate financial resources for them. As observed by Mello, Blondal and Pain (2020), the COVID-19 pandemic is taking a substantial toll on the economies and societies. At the pandemic's onset, governments worldwide imposed stringent measures 
to contain the spread of the virus. These measures resulted in significant short-term economic disruption and job losses, compounded by falling confidence and tighter financial conditions. It is important to note that the levels of poverty will be aggravated globally unless meaningful interventions are employed by countries at national, regional and global levels. This will pose a challenge in the realisation of sustainable development goals, particularly by the African countries, which were already struggling even before the outbreak of the pandemic. As noted by Collier and Gunning (1999) Africa has had slow growth and a massive exodus of capital. In many respects it has been the most capital-hostile region.

As noted by Cuaresma. et.al (2018) the largest differences in poverty headcount and poverty rates across scenarios appear for Sub-Saharan Africa, where the projections for the most optimistic scenario imply over 300 million individuals living in extreme poverty in 2030. The results of the comparison of poverty scenarios point towards the difficulty of fulfilling the first goal of the SDGs, unless further development policy efforts are enacted. It is important to note that it is in the design of policies as proposed by Cuaresma and others that lifelong learning should be instrumental in providing the necessary training to the people on how they can gravitate towards better economic undertakings. Most importantly, in the appreciation of the impact the pandemic has had in the global efforts to escape poverty.

The people should be fully informed about how fast the world will change on its recovery programmes post COVID 19, which dictates that lifelong learning programmes should be fully utilised. As observed by Laal and Salamati (2012), our world is changing around us in such a frantic pace that if we do not continue to grow and develop; we will soon be left behind. In the 21 st century, we all need to be lifelong learners. It is important to note that this observation was made before the pandemic devastated the world. Notably, the world was already moving faster and making the skills and knowledge that people acquire become obsolete very fast, which necessitates lifelong learning.

The COVID 19 pandemic has further made lifelong learning even more significant on one hand and Sustainable Development on the other hand. It is in the understanding that Sustainable Development cannot be achieved in isolation that lifelong learning is found to be apt in fostering the changes that are necessary post the pandemic. As noted by UNDP (2012), from the climate crisis and Covid 19 pandemic to rising inequalities and protracted conflict- these challenges cannot be dealt with in isolation, hence the need to educate the people about the relationship that exists between them. The way countries respond and the solutions they develop must be integrated and fully supported by the people who are educated about them. As stated by Emas (2015), Sustainable Development requires the elimination of fragmentation; that is, environmental, social and economic concerns must be integrated throughout decision making processes in order to move towards development that is truly sustainable.

The mind-set of the leaders should be changed, so that they can have the understanding that misappropriation of state funds will lead to the level of impecuniousness that will work against the economic recovery of their countries. As noted by Oduor (2018), even as the pandemic continues to ravage the world, some countries have reported continued theft of Covid-19 response funds. In Africa, several countries have reported rampant corruption and theft of cash and other incentives meant to cushion against the impacts of the disease. It is disquieting that the poorest continent is also characterised by the embezzlement of its resources even during the pandemic, hence the need for the education of its leaders to fight corruption determinedly to save their economies from irredeemable collapse.

It is worth indicating that corruption is an impediment against Sustainable Development because it does cause environmental problems. As noted by UNDP Botswana (2012), corruption also aggravates environmental problems through the illegal dumping of hazardous waste and the illegal trade in animal and plant life, facilitated by bribery and under-the-table incentives that determine who is awarded contracts, especially for highly lucrative, large-scale infrastructure projects. Sustainable Development goals such as clean water and sanitation, affordable clean energy, climate action, life on land, life below water and good health and wellbeing can be jeopardised through corruption.

The exportation of African misappropriated resources should be ended by countries to which such resources are exported. This is important if the continent is to remain routed to the realisation of Sustainable Development. It is important to utilise lifelong learning for the purpose of disseminating knowledge about the negative effects of corruption on ailing economies. Available information from national, regional and international entities meant to combat corruption should be used in the education of the leaders. As noted by African Development Bank Group (2021) The African Development Bank and the Organization for Economic Co-operation and Development (OECD) led calls among partner institutions for greater vigilance to tackle corruption and ensure the best environment to build back African economies after the Covid-19 pandemic. The International Monetary Fund (IMF) and the World Bank should embark on the design of training programmes that are meant for African leaders to fight corruption. This is important as such trained leaders will release resources for the training of people about corruption, which include provision of such training through both modern and traditional schools, religious institutions and universities.

As noted by Shang-Jin (2001) IMF is put in charge of minimizing the risks associated with globalization and the likelihood of currency crises. It is important to note that corruption may make a country more vulnerable to the risks of a currency crisis. Therefore, lending support to anti-corruption efforts in the developing countries is very much consistent with the central mission of the IMF. It is important to also note that, The World Bank Group considers corruption a major challenge to its twin goals of ending extreme poverty by 2030 and boosting shared prosperity for the poorest 40 percent of people in the developing countries (The World Bank (2020). 
It is important for local entrepreneurs, including those in the entertainment industry to be given skills in financial literacy, so that they can run their businesses profitably and professionally. The indigenous farmers should also receive training in food production in line with Sustainable Development goals such as, poverty alleviation, zero hunger and good health and wellbeing. As noted by Thakkar (2021) Africa must move away from overly relying on imports and focus on supporting locally produced products in order to retain profits and support job creation and economy-building initiatives.

The tourism industry that continues to suffer dreadfully during COVID 19 pandemic, should be capitalised and skilled in new strategies that can attract tourists to the African continent. This requires countries in Africa to spend resources in importing exotic species, such as Indian tigers, polar bears and fishes that are currently not available in the continent. It is therefore important for African countries to provide education to its rural communities on the importance of tourism, which should promote conservation and be against speciesism. Provision of such knowledge and skills through Lifelong Learning programmes will inevitably empower locals to be responsive to the goals of Sustainable Development such as, climate action, life and land, clean water and sanitation and affordable and clean energy. Lifelong learning can play some pivotal role in equipping the people with knowledge, skills and attitudes that are required to revamp the tourism sectors in the African countries. As observed by Asian Conference on Education [ACE] (2010) Lifelong learning is seen to enhance human capital, giving workers the skills and training they need to participate in a competitive global economy.

In the creative sector, the restrictions negatively affected the economic contributions that the sector add to the national economies. As noted by OECD (2020) cultural and creative sectors are important in terms of their economic footprint and employment. They also spur innovation across the economy, as well as contribute to numerous other channels for positive social impact (well-being and health, education, inclusion, urban regeneration, etc.). However, the sector is globally amongst the hardest hit by the pandemic. It is important to train people through financial literacy programmes so that those who are the beneficiaries of the industry can diversify their investments. To enhance productivity in the sector, it is also important for countries such as Botswana, to take the deployment of ambassadors seriously than to engage political activists from the ruling party who perform dismally during elections. The ambassadors should be people who are selected on merit. It should be individuals who possess understanding of global politics and economics, so that they provide knowledge about African cultures in foreign countries where they are based. The ambassadors from the continent should be deployed following intensive training, so that they exploit available economic, political and social opportunities for the benefit of their countries.

\section{Political irrationality}

The preservation of human lives has globally exposed the political deceptiveness and unreasonableness of some countries, but most importantly the highest levels of unpreparedness of most of them. It is worth noting that countries did not know about COVID 19 until 2019. However, this cannot be used to justify why most African countries did not display that they were prepared for any disaster that could happen anytime. The health sectors are getting overstretched, and the logistical challenges are evident, mostly in African countries that are behind in development. As noted by Tadesse (2020), Covid-19 has revealed not only the obvious weaknesses of our health systems but also how we have underestimated health in our development agenda. We were unprepared, even though international public health agencies such as the World Health Organization, and prominent global figures, flagged threats years ago. The situation indicate that countries will need to work even more if they are to realise Sustainable Development. According to Bonn (2021):

The COVID-19 pandemic is impacting many sectors of society, such as health, education, economy, which are related to thematic issues covered by the SDG3 (Health \& Well-Being), SDG4 (Quality Education), SDG8 (Decent Work \& Economic Growth), SDG12 (Consumption \& Production), SDG13 (Climate Action), etc.

It is very important for political leaders in developing countries to know that poverty is a disaster that only serve to aggravate conditions of those who are poor when a new disaster strikes. The inability of poor countries to fight poverty have only resulted in worsening conditions of the poor due to COVID 19. For instance, in countries such as Botswana where some poverty-stricken individuals survive by eating the food that is cooked for mourners during funerals, they are highly likely to get malnourished due to restrictions that were imposed to curb the spread of the virus. The food is not prepared and distributed as was the case before the outbreak of COVID 19. It is worth noting that only a few people are allowed at funerals, weddings and any other social gatherings. This means poor people are disadvantaged as they can no longer get free food that is normally provided in social gatherings before disruptions caused by protocols imposed to curb the spread of COVID 19. The government of Botswana did not provide enough food during lockdowns, which further compromised the nutritional standard of the people who could not fend for themselves.

In Uganda, as stated by Nathal and Benon (2020), the relief response campaign received a lot of critics from both rural and urban communities who were to be targeted as the beneficiaries. Three months into the COVID-19 pandemic, the population reported delays in the distribution, poor quality supplies, arrests and continued restrictions, slow paced distribution among households, and a negative impact on the health care system. In Zimbabwe people received assistance because USAID played some pivotal part in the distribution of food. As noted by Machoko (2020), when COVID-19 hit, the lockdown measures made putting food on the table even more difficult for millions of Zimbabweans. We worked with our partner, the World Food Programme (WFP), and quickly modified food distribution practices to keep staff and food assistance recipients 
safe. Together with WFP, we reached vulnerable people with food assistance, while reinforcing social distancing and hand washing at distribution sites. In just two weeks, USAID, through WFP, provided food for more than 930,000 vulnerable Zimbabweans.

It is evident that the poor countries do not demonstrate their full commitment to meet the exigencies of the citizenry, despite having to fulfil Sustainable Development goals. As indicated by Jerving (2020), before the pandemic hit, The African Development Bank estimated that the number of people living in extreme poverty, defined as people living on less than $\$ 1.90$ per day, could reach 425.2 million in 2020. But it revised that number to between 453.4 million and 462.7 million - an increase of up to 37.5 million.

Part of the problem in Africa is the level of corruption that takes away resources from the people of the continent who need them most, to finance lavish lifestyles of continental leaders. As observed by Oduor (2021) in Kenya, KEMSA is under fire over allegations that government officials and businessmen pilfered $\$ 400$ million in public money earmarked for medical equipment needed in the fight against coronavirus. Investigations are currently underway, but no one is taking the blame as all fingers point into a well-orchestrated deal set up by government officials. The African countries can not realise Sustainable Development goals if corruption remains as rampant as it is now. This also calls for developed countries to disallow corruptly obtained resources from the African continent to find places into commercial entities, such as commercial banks ashore. As noted by United Nations (2020):

Illicit financial flows and corruption are inhibiting African development by draining foreign exchange, reducing domestic resources, stifling trade and macroeconomic stability and worsening poverty and inequality. These illicit flows rob Africa and its people of their prospects, undermining transparency and accountability and eroding trust in African institutions. Faced with high capital flight, tax avoidance and a marked dependence on corporate income taxes, African governments face significant constraints to widening their tax base.

It is important to note that Africa faced with financial problems as highlighted by the United Nations cannot fully and timely realise Sustainable Development goals, such as ending poverty, protection of the planet, making sure that by 2030 all people enjoy peace and prosperity, quality education, gender equality and reduced inequalities. This means Africans will remain submerged in poverty and face uncertain future even beyond 2030. The United Nations (2020) further indicate that, curbing illicit financial flows is an avenue for providing African countries with additional funds towards achieving Agenda 2063 and the Sustainable Development Goals. The undertakings that are necessitated to halt the stealing of resources from the African countries should be coupled with very strong global legislations against leaders who do not demonstrate required level of commitment towards fighting corruption and poverty. All countries should be made to report periodically to the United Nations on their agendas towards the realisation of Sustainable Development. The countries should be encouraged to provide training in the area of Sustainable Development through Lifelong learning programmes at both national and regional levels. As noted by Antonio Guterres, who is the Secretary General of the United Nations in 2021 pointed out that, "turning the tide against corruption is essential if we are to achieve the Sustainable Development Goals (SDGs), promote peace, and protect human rights". The UN Secretary General went further to indicate that, ending impunity for corruption, and returning stolen assets to their owners, are important steps towards a new social contract based on trust, integrity and justice.

The other major problem that is synonymous with developing countries, such as Botswana, is the corrupt leaders who appoint people to positions of responsibility not based on merit, but on political affiliation, tribal identity, regionalism and sycophancy. This irresponsible behaviour has led to the deaths of innocent people in some cases because of ill-functioning of people so appointed. The countries mostly those in the African continent have also lost large sums of money because people who are supposed to investigate cases that involve criminals that are related to corrupt leaders are inhibited. In Botswana, at the outbreak of COVID 19 a task force was formed, which had an animal scientist at its peak. The task force was manned by pure scientists who lacked germane judgement on how the people were likely going to spread the virus, such as through rituals that are undertaken during religious and traditional undertakings. Some religious and traditional entities induce spewing or vomiting by the members to exorcise bad spirits and curing of ailments. During such practices there is often sharing of utensils, which is partially responsible for the transmission of COVID 19 virus. It is therefore important for countries to contextualise their interventions, to avoid absolute reliance on exotic approaches. It is therefore important through Lifelong Learning programmes for countries to educate the citizenry about the pandemic in an indigenised manner. The undertaking should include the education of indigenous people, such as Basarwa in Botswana, using their indigenous languages. As noted by UNESCO (2020):

good communication, including effective use of existing primary health care networks, accurate and timely information in appropriate languages, and involving those from within indigenous communities to help conceptualise prevention and care strategies is important. Spaces for participation and dialogue can address the current emergencies but also contribute to economic and social recovery plans. 
The other area that during the tackling of COVID 19 proved to be crucial is that of foreign representation. The appointment of ambassadors in Botswana has been partisan and meant largely to benefit those members of the ruling party who do not emerge victorious at either primary or national elections. This arrangement compromises the quality of representation of the country, which evidently result in it not getting the benefits that it could otherwise get from other countries and international bodies.

The developing countries have also got a problem of leaders who spend a lot of financial resources from the state in funding their lavish lifestyles, which leaves the citizens of such countries in abject poverty. This obviously creates some impediments towards the realisation of the Sustainable Development goals. As noted by The East African Magazine (2014):

The lifestyles of African presidents and their families reflect the tragedy of resource-rich African countries where the leaders spend millions on luxury items, as the ordinary people live in abject poverty, lacking access to basic amenities and services such as clean drinking water, health care and education.

In eSwatini, according to This is Africa (2018) beside renaming the country on its $50^{\text {th }}$ Independence Day celebrations, the King of eSwatini also saw fit to gift himself a R2, 7 billion Airbus A340-300 for his 50 th birthday, which coincided with the former. It is important for the leaders of developing countries to be educated through Lifelong Learning programmes on financial literacy and development. This should be undertaken by their universities and international institutions such as the Bretton Woods. This must embrace implications of spending resources extravagantly and ignoring the poor, which often leads to civil unrest. It must be made clear through such training that this situation has led to civil unrest in most developing countries, which has negatively affected development efforts in the continent. It must be admitted that political leaders, mostly Presidents and Prime Ministers, do not often get the necessary training so that they can function effectively in their positions. This calls for the training that should be designed to fulfil the agendas such as Sustainable Development goals, which can enhance governance and accountability. The promotion of democracy through peace education in the world should form the cornerstone of the mission towards realisation of Sustainable Development. It must be noted that the international community's wilful avoidance of governance issues for the previous half-century of development lending undermined aid effectiveness, at worst, supported authoritarian regimes which impoverished their countries and repressed their citizens (Abide, 2010).

It is important to indicate that lifelong learning programmes should promote leadership that values the services to the led than self-enrichment. As observed by Akins, Bright, Brunson and Woody (2013) ten leadership qualities identified as part of the Sustainable Development for leadership include learn, empower, adapt, develop, engage, reflect, sustain, humility, integrity, and practice. These qualities are vital for the leadership in its ability to confront future Sustainment Development challenges.

\section{Social Transformation}

The COVID 19 has affected countries differently, but what can be admitted is that it has affected how people lead their lives, due to restrictions that are employed to combat it. As noted by Bruns, Kraguljac and Bruns (2020), cultural methods of greeting such as shaking of hands or a kiss on the face are widely adopted greetings internationally but may contribute to the spread of viruses and bacteria. Several countries have recommended against hand shaking and other traditional forms of greeting such as kissing on the check and the "nose to nose" greeting.

In addition to the prohibitions, most African countries, such as South Africa have restrictions pertaining to a number of mourners that are allowed to attend a funeral. The provision of cooked food at funerals and weddings is also not allowed. These restrictions are in some instances violated, which requires training that will promulgate their value to the people. The outlawed practices do have some negative cost implications on the bereaved families. In Botswana for instance, a bereaved family is required to slaughter animals such as cattle and provide food to feed the mourners. The practice does exact pressure on families with limited means as they are expected to provide food just as those with the means. It has also reduced animals such as cattle, goats and sheep in countries that honour such practices, such as Botswana. According to Minister of Agricultural Development and Food Security Mr Karabo Gare, Botswana used to boast a cattle population of around three million, but it has since declined to 1.5 million (Botswana Daily Newspaper, $1^{\text {st }}$ March, 2021). Though the reduction is attributed partially to climate change, the killing of cattle during funerals and weddings does contribute to the plummeting of their numbers. It is important for the Ministry of Agriculture Development and Food Security and Ministry of Youth Empowerment, Sport and Culture Development to design programmes that will be aimed at making their recipients to appreciate maintaining of the reforms that are brought about as part of the COVID 19 protocols, such as permanently stopping the slaughtering of cattle during funerals and weddings. The lifelong learning programmes should be designed to reduce poverty within pastoral and arable farmers, who slaughter their livestock to fulfil cultural requirements of feeding people at funerals and weddings. 
The use of land in countries that do not cremate is under pressure because of increased mortality resulting from COVID 19 pandemic. In South Africa, according to Naidoo (2019) the South African population is in excess of 57 million (and) is also growing exponentially and faces the same situation of having to find 57 million graves within 50 to 80 years. There is also another problem that is associated with use of land. It is important to note that underground water gets contaminated due to decomposed corpses in cemeteries. As observed by Migliorini as cited by Zychowski and Bryndal (2015), the adverse impact of cemeteries on groundwater caught the attention of scientists at the end of the nineteenth century. In 1879, the French Society for Hospital Hygiene noticed the relationship between typhoid fever and groundwater contaminated by leachates from a cemetery in Paris. Zyxhowski and Bryndal goes further to indicate that, it is worthy presenting an investigation result concerning the migration of bacteria performed by Matos in 2001 in the Vila Nova Cachoeirinha cemetery. The studies revealed that bacteria may migrate over several metres beyond the cemetery. Viruses turned out to be more mobile than bacteria. The viruses were also transported at least $3.2 \mathrm{~m}$ through the unsaturated layer and reached the groundwater layer.

If countries are to achieve the Sustainable Development goals of clean water and sanitation as well as good health and wellbeing, it is important that people are educated about the value of incineration of corpses to avoid contamination of underground water. It is therefore important for programmes to be designed by environmentalists and facilitated at schools, churches and universities to promote conservation through prudent use of land and prevention of avoidable contamination of water due to decomposed human remains. It is worth noting that according to International Institute for Sustainable Development (2021) 2 billion people lack safely managed drinking water and 3.6 billion people lack safely managed sanitation. It is important for governments through their ministries and organisations that are responsible for environmental resources to design programmes to educate their citizenry about the importance of conservation and natural resource management. As noted by Medel-Anonuevo, Ohsako and Mauch (2001) Lifelong Learning is the panacea for all problems, as it can easily be offered as an appropriate remedy for practical thinkable crisis people are faced with on both macro and micro level. As indicated by mentioned authors, Lifelong Learning can play an important role in making sure that Sustainable Development goals are achieved with full participation of the people.

A good global social transformation agenda should be that which is aimed at digitisation and digitalisation of the agricultural sector. It is important therefore for countries to provide agricultural education to both commercial farmers and peasants because the sector has the potential to uplift standard of living of global citizens and end abject or absolute poverty. The change of mind-set of farmers through agricultural education programmes is fundamental. As observed by Giesler (2018), Agriculture should utilise automated steering systems, data-driven targeted application of fertilisers and pesticides, field robots and drones, soil analysis sensors, autonomous driving because digitisation should advance in agriculture. Digitisation clearly creates the conditions for successful agricultural practices. This requires well thought-out and capitalised agroindustrial monetary policies in countries such as Botswana, Lesotho and eSwatini that are import dependent.

\section{Conclusion}

The paper discussed a very important point about Lifelong Learning, pointing out that for Sustainable Development to be achieved the former should be instrumental in that accomplishment. The emergence of the devastating COVID 19 pandemic, which has caused economic, political and social challenges has made the realisation of Sustainable Development difficult, which places Lifelong Learning at the centre stage in educating the global population about the debilitating situation and how it can be mitigated. It did advance that Lifelong Learning programmes should be embarked upon so that countries can realise their post COVID 19 recovery undertakings. The countries in their quest to realise post-Covid 19 recovery they should be corruption free because as the paper advocates, it has even before the pandemic proven to be working against efforts to provide for the citizenry in developing countries.

It was found as important also that in most instances the leaders who take political leadership positions do not always receive training to prepare them to undertake their responsibilities conscientiously. It was found out that poverty-stricken countries in majority of the cases get their conditions aggravated if a pandemic or any form of disaster besieges.

Noticeably, the paper revealed that corruption is rampant in Africa and is partly responsible for challenges that would make the realisation of Sustainable Development insurmountable. This situation requires that Lifelong Learning should be resuscitated or revivified, so that it becomes more responsive, which is necessary for the realisation of Sustainable Development. This therefore requires people to be educated so that they get to contribute meaningfully towards Sustainable Development.

\section{References}

Abide, C.E. (2010) Accountability in Africa and international community. Journal of Social Research. Vol.77, No.4, pp.1241-1280. Johns Hopkins University Press. http://www.jstor.org/stable/23347126.

African Development Bank Group (2021) Fighting corruption in Africa: African Development Bank and OECD call for greater vigilance to ensure business integrity amid COVID 19 crisis. Cote Divoire: African Development Bank Group. 
Akins, R. Bright, B. Brunson, T. and Woody, W. (2013) Effective leadership for Sustainable Development. Journal of Organisational Learning and Leadership. Vol.11. No.1. pp.29-37.

Asian Conference on Education [ACE] (2010) The second Asian Conference on Education: 'Internationalization or Globalization? Osaka.

Botswana Daily newspaper ( $1^{\text {st }}$ March, 2021) Botswana cattle numbers plummet. Gaborone: Botswana Government Print.

Bruns, D.P. Kraguljac, N.V. and Bruns, T. (2020) COVID 19: Facts, cultural considerations, and risk of stigmatisation. Journal of Transcultural Nursing. Available: https://doi.org/10.1177/1043659620917724. Retrieved on the $25^{\text {th }}$ July, 2021.

Carlsen, A. (2015) UNESCO Global Network of Learning Cities. Hamburg: UNESCO Institute for Lifelong Learning (UIL).

Collier, P. and Gunning, J.W. (1999) Explaining African economic performance. Journal of Economic Literature, Africa has had slow growth and a massive exodus of capital. In many respects it has been the most capital-hostile region.ol.37, No.1.pp.64 -111.

Cuaresma, J. Fengler, W. Kharas, H. Bekhtiar, K. Brottrager, M. and Martin, H. (2018) Will the sustainable development goals be fulfilled? Assessing present and future global poverty. Humanities \& Social Communications. Palgrave Communications.

Encarta (2008) Lifelong learning. (Retrieved from: http://encarta.msn.com/dictionary 56154717/lifelong learning.html (on the $14^{\text {th }}$ August, 2021).

Giesler, S. (2018) Digitisation in Agriculture-from precision farming to farming 4.0. Retrieved from BIOPRO BadenWürttemberg GmbH. (Retrieved on the $23^{\text {rd }}$ August, 2021).

Guterres, A. (2021) Turning tide against corruption essential to achieving Sustainable Development goals, promoting peace. Secretary General Speech at GlobE network launch on the $3^{\text {rd }}$ June, 2021. United Nations.

Illeris, K. (2010) Towards a contemporary and comprehensive theory of learning. Available: https://doi.org/10.1080/02601370304837. (Retrieved on the $27^{\text {th }}$ June, 2021).

International Institute for Sustainable Development (2021) SDGs report 2021: COVID 19 led to first rise in extreme poverty in a generation. Earth Negotiations Bulletin.

Jerving, S. (2020) The pandemic could push nearly 50 million more Africans into extreme poverty, AFDB says. Devex.

Laal, M. and Salamati, P. (2012) Lifelong Learning; why do we need it? Procedia- Social and Behavioural Sciences. Vol.31, pp.399-403.

Machoko, E. (2020) Everything virtual during the COVID 19 pandemic: Remote monitoring, one food distribution at a time! Zaka, Masvingo Province, Zimbabwe: USAID.

Medel-Anonuevo, C. Ohsako, T. and Mauch, W. (2001) Revisiting Lifelong Learning for the $21^{\text {st }}$ Century. Hamburg: UNESCO Institute for Education.

Mello, L. Blondal, S. and Pain, N. (2020) The COVID 19 crisis and the global economy: challenges and policy requirements. http://www.theigc.org (Retrieved on the $29^{\text {th }}$ June, 2021).

Nathal, I. and Benon, M. (2020) COVID 19 relief food distribution: impact and lessons for Uganda. The Pan African Medical Journal, 35 (suppl. 2:142. Bethesda: National Centre for Biotechnology Information, US. National Library of Medicine.

Oduor, M. (2018) Africa's COVID 19 corruption that outweighs the pandemic. Africa Economy. AFricaNews.

Oduor, M. (2021) African's Covid 19 corruption that outweighs pandemic. Africanews.

OECD (2020) Cultural shock: COVID 19 and the cultural and creative sectors. Available on OECD.org (retrieved $19 / 06 / 2021)$.

Shang-Jin, W. (2001) Corruption and Globalisation Report. Brookings Policy Brief Series.

Shereen, M.A. Khan, S. Kazmi, A. Bashir, N. and Siddique, R. (2020) COVID 19 infection: Emergence, transmission, and characteristics of human coronaviruses. Journal of Advanced Research. Vol.24. pp.9198. http://doi.org/10.1016/j.jare.2020.03.005 (Retrieved on the 20 th June, 2021).

Shulla, K. (2021) Accelerating global actions for a world without poverty. Virtual inter-agency expert group meeting on implementation of the Third United Nations decade for the eradication of poverty (2018-2027). Albania: University of Bonn.

Tadesse, L. (2020) “Three lessons learnt from COVID 19 and other emergencies”. In Kaberuka,D. 12 leaders' perspectives on supporting Africa's health systems through Covid-19. London: ODI.

Thakkar, A.J. (2021) Long-term strategies for an African recovery from COVID 19: A CEOs perspective. Africa in Focus, The Brookings Institution.

The East African Magazine (2014) The lives of the filthy rich African Presidents and their families.

The World Bank (2020) Combating corruption. Washington DC: IBRD-IDA.

This is Africa: Politics and society (2018) King Mswati; lifestyles of the rich and royal. tia@rnw.org.

UNDP (2012) impact of COVID 19 on the sustainable development goals. Financial sector hub Service Portal. 
UNDP Botswana (2012) Corruption destroys opportunities and creates rampant inequalities. UNDP.

UNESCO (2015) UNESCO Global Network of Learning Cities. Hamburg: UNESCO Institute for Lifelong Learning (UIL). UNESCO (2020) COVID 19 recovery and indigenous peoples. Retrieved from www.UNESCO.org. (On the 22 ${ }^{\text {nd }}$ August, 2021).

United Nations (2020) Economic Development in Africa Report 2020: Tackling illicit Financial flows for Sustainable Development in Africa. New York: UNCTAD/AIDC/Africa/2020.

World Bank (2019) Botswana. The World Bank Group.

Zychowski, J. and Bryndal, T. (2015) Impact of cemeteries on groundwater contamination by bacteria and viruses- a review. Journal of Water and Health. Vol. 13, (2), pp.285-301. 